Amiruddin

\title{
IMPLEMENTASI PENDIDIKAN AG AMA DAN KEAGAMAAN PASCA KONFLIK DI POSO SULAWESI TENGAH
}

Oleh: Amiruddin

\begin{abstract}
Abstrak
This research aims to describe the implication of social conflict to education of religion (formal and informal) implementation. This was conducted at Poso, Midle Sulawesi. Data was collected by depth interview and observation.

This research indicates that social conflict atAralle, Tabulahan, Mambi during 2002-2005 had give impact the some education of religion implementation, such as (a) number of teachers and students was decrease. Most of them went out to another place; (b). Some students have different perspective after this conclict, for example; several students deny learning English, because it s non-Moslem language.

Local government regulate a lot ofprogram to heal this effect of conflict, such as (a) empowering religion organization (Muhammadiyah, NU etc) to take active role; (b) facilitating dialog between moslem and Christ people.
\end{abstract}

Key word: conflict, education, religion, implementation.

\section{PENDAHULUAN}

alah satu ciri khas masyarakat dan bangsa Indonesia ialah pluralitas atau kemajemukan dalam berbagai hal, dan kemajemukan itu telah melahirkan perpaduan yang sangat indah, yaitu masyarakat yang hidup berdampingan secara damai dalam berbagai bentuk kultur sosial budaya, berbagai suku dan agama yang dapat di pandang sebagai asset dan potensi bangsa yang pendayagunaannya dapat diarahkan untuk menumbuhkan semangat kerjasama 


\section{Amiruddin}

dan integritas yang memang diperlukan dalam rangka stabilitas nasional dan keutuhan bangsa. Namun pada sisi lain kemajemukan itu dapat menjadi potensi untuk sewaktu-waktu dapat memunculkan ketegangan atau konflik.

Di samping itu era globalisasi juga menghadapkan masyarakat kepada serangkaian tantangan baru berupa pemikiran/faham yang berdampak luas terhadap hidup dan kehidupan umat manusia tidak terkecuali pendidikan agama dan keagamaan. Oleh sebab itu tampaknya pendidikan agama dan keagamaan melalui institusi dan media, keberhasilannya masih dipertanyakan akibat dari berbagai ketegangan yang terjadi dalam masyarakat baik yang berskala kecil, maupun besar yang bernuansa Suku, Agama Ras dan Golongan (SARA). Sejak tahun 1996 peristiwa ketegangan berupa konflik, kerusuhan, prasangka streotif dan kesenjangan social yang terjadi dibeberapa daerah antara lain yang terjadi di Maluku, Mataram (NTB) dan Poso (Sulteng) bahkan jauh sebelumnya terjadi pula di Aceh. Ketegangan tersebut telah menghancurkan dan meluluh lantahkan tatanan sosial kehidupan dalam masyarakat dan telah menelan korban jiwa, harta, kehormatan dan akan berpengaruh pada berbagai tatanan hidup masyarakat dan institusi social, antara lain institusi pendidikan formal maupun non formal.

Menyadari akan urgensinya dalam kehidupan bangsa Indonesia, maka dalam pasal 3 Undang-Undang Nomor 20 tahun 2003 tentang Sistem Pendidikan Nasional disebutkan bahwa pendidikan Nasional berfungsi mengembangkan kemampuan dan membentuk watak serta peradaban bangsa yang bermartabat dalam rangka mencerdaskan kehidupan bangsa, bertujuan untuk kembangkan potensi peserta anak didik agar menjadi manusia yang beriman dan bertakwa kepada Tuhan Yang Maha Esa, berakhlak mulia, sehat, beriman, cakap, kreatif, mandiri dan menjadi warga

Salah satu bentuk konflik sosial sifatnya multidimensional yang kemudian bernuansa pertentangan kepentingan antar umat berbeda agama ialah konflik sosial di Kabupaten Poso, Provinsi Sulawesi Tengah. Konflik ini berawal dari tahun 1998 hingga sampai tahun 2001, telah terjadi 4 kali kerusuhan yang dalam sejarah disebut kerusuhan jilid 1 sampai dengan jilid 4, disetiap klimaks selalu memperhadapkan dua kelompok yang bertikai dalam jumlah yang besar dan terlibat dalam aksi perkelahian, aksi pembunuhan, pengrusakan dan pembakaran rumah, tempat ibadah, pendidikan (sekolah) maupun sarana umum lainnya, yang mengakibatkan ribuan orang meninggal dan terluka, puluhan ribu orang mengungsi serta banyak warga yang kehilangan harta benda. 
Dampak dari ketegangan sosial tersebut juga telah dirasakan oleh pendidikan agama dan keagamaan disuatu lembaga pendidikan. Pendidikan agama dan keagamaan tersebut tidak menghidupkan pendidikan multikultural yang baik, bahkan cendrung berlawanan, lembaga pendidikan terkadang menafikan pendidikan dan hak hidup agama lain, hal ini terjadi dikalangan mayoritas maupun minoritas. Semangat pendidikan agama dan keagamaan seperti ini berlawanan secara fundamental dengan semangat pendidikan multicultural dan melemahkan persatuan dan kesatuan bangsa.

Melihat fenomena di atas, maka penting kiranya dilakukan studi terhadap Implementasi pendidikan agama di daerah yang pernah mengalami konflik, untuk memperoleh gambaran tentang implementasi pendidikan agama dan keagamaan didaerah tersebut. Hasil studi ini nantinya dapat dijadikan titik pijakan bagi pemerintah dalam pengambilan kebijakan khususnya di bidang pembangunan pendidikan agama dan keagamaan.

Penelitian ini bertujuan untuk menelusuri bagaimana implementasi pendidikan agama dan keagamaan pasca konflik, serta bagaimana dampak yang ditimbulkan terhadap pendidikan agama dan keagamaan didaerah yang pernah berkonflik di kawasan Timur Indonesia.

Kegunaan Penlitian ini diharapkan hasilnya dapat dijadikan sebagai bahan masukan bagi perumusan dan pengambilan kebijakan bagi pemerintah dalam rangka pengambilan keputusan tentang pembangunan terutama pembangunan di bidang agama.

Penelitian ini dilaksanakan di Provinsi Sulawesi Tengah dengan sasaran lokasi penelitiannya di Kabupaten Poso dengan mengambilan salah satu dari 15 kecamatan yang ada di Kabupaten Poso yaitu Kecamatan Poso Kota dengan pertimbangan letaknya berada ditengah kota dengan sarana pendidikan yang cukup memadai.

Teknik pengumpulan data menggunakan wawancara mendalam dan observasi, Setelah data terkumpul, dilakukan pengolahan data sesuai dengan sifatnya. Data yang sifat kualitatif, terutama dari hasil wawancara bebas dan hasil observasi diolah secara kualitatif sesuai dengan jenis data dan tujuan penelitian. Selanjutnya dilakukan pengelompokan data dengan memperhatikan data yang sejenis dan data yang memiliki perbedaan antara satu sama lainnya. Kemudian diidentifikasi keterkaitan di antara data tersebut, terutama faktor yang menghubungkannya dan interpretasi data dilakukan tanpa mengabaikan data emik dan etik. 
masyarakat Kabupaten Poso. Sebab bertentangan dengan budaya Sintuwu Maroso. Hal ini menjadi pergumulan seluruh komponen masyarakat baik perorangan maupun lembaga sosial, ekonomi, lembaga keagamaan dan lembaga politik di Kabupaten Poso. Karena setidaknya dampakyang ditimbuIkan antara lain telah memporakporandakan hasil pembangunan di Kabupaten Poso.

Imbas kerusuhan juga sangat dirasakan disektor pendidikan, baik sekolah umum maupun sekolah berlabel agama. Sekolah yang dulunya terdapat pembauran antara beberapa etnik dan agama tapi akibat adanya konflik terjadi segregasi, sehingga ada sekolah yang siswanya seratus persen muslim dan ada juga sekolah yang siswanya seratus persen Kristen. Ini bisa menimbulkan disharmonis karena sudah tidak ada pluralitas dan multikultural yang bisa dijadikan perekat kerukunan, di samping itu otomatis proses belajar mengajar tidak berjalan sesuai kalender pendidikan. (Hasil wawancara Kasi Mapenda Depag Poso).

Menurut kepala sekolah SMA Negeri 3 Poso Dra. Ratna mengungkapkan bahwa, Konflik sosial yang terjadi di Poso telah melemahkan institusi pendidikan karena sebagian siswa yang ada disekolah telah menampakkan keengganan untuk mempelajari pelajaran yang tidak sesuai dengan doktrin agamanya, misalnya mereka tidak mau belajar bahasa Inggris karena menganggap haram untuk mempelajarinya dan mereka tidak mau diatur lagi di sekolah sehingga malasmalasan masuk sekolah, karena dia menganggap bahwa sekolah itu bukan ibadah. pola keberagamaan sebagian siswa sudah dirasuki oleh pemahaman konsep jihad yang disalah tafsirkan sehingga menimbulkan tingkah laku yang ekstrim terhadap apa yang tidak sejalan dengan yang difahaminya. Sedangkan dampak yang ditimbulkan dikalangan guru agama terkhusus di SMA Negeri 3 Poso telah terjadi segregasi, yang dulunya terdapat beberapa guru agama Kristen namun sekarang sudah pindah ke sekolah lain, sehingga untuk mengisi kekosongan mata pelajaran agama Kristen terpaksa gurunya di pinjam dari sekolah lain.

Semua pihak telah merasakan akibat yang ditimbulkan oleh kerusuhan, derita dan kesulitan disektor perekonomian dengan kurangnya kebutuhan pokok dan tingginya harga-harga kebutuhan sehari-hari yang menimbulkan krisis ekonomi. Untuk itu mereka mengharapkan agar suasana yang sudah kondusif ini tidak terulang lagi. Seluruh komponen dan elemen masyarakat Poso telah bertekat untuk mengubur dalam-dalam tragedi yang telah terjadi di tanah Poso.

\section{Kebijakan Pemerintah terhadap Pendidikan Agama dan Keagamaan}

Bila diperhadapkan dengan kenyataan pembangunan di Kabupaten Poso pasca konflik masih perlu menjadi pergumulan kita bersama. Sebab prioritasnya 
Amiruddin

masih lebih besar berorientasi kepada pembangunan yang kelihatan dan terukur. Itupun ketepatannya dalam menyelesaikan masalah mendasar sesuai kebutuhan masyarakat Kabupaten Poso masih perlu dipertanyakan dalam artian kebijakan Pemerintah belum sepenuhnya memenuhi sasaran.

Berbagai upaya yang telah di tempuh oleh pihak pemerintah baik pusat maupun daerah dalam merekonsiliasi dan menata kembali wajah Poso yang telah terkoyak akibat kerusuhan. Seluruh potensi telah dikerahkan yang berdampak pada bagaimana menyatukan dan merekatkan kembali pola interaksi yang selama ini terbina dengan baik. Langkah-langkah yang telah dilakukan oleh pemerintah antara lain:

- Mengadakan kemah lintas agama pada tahun 2006 yang menghadirkan seluruh komunitas yang bertikai yang diresmikan oleh bapak Menteri Agama.

- Melakukan Dialog Lintas Agama (wawasan Keagamaan).

- Membentuk dan mengaktifkan dialog Forum Komunikasi semacam FKUB dan BKAUB.

- Mengadakan pelatihan dan Workshop kepemudaan.

- Studi banding ke Manado untuk melihat fenomena keberagamaan yang tetap rukun walaupun sarana ibadah berdampingan, tapi tetap rukun dan damai.

- Di samping kegiatan keagamaan, pemerintah juga mengaktifkan kegiatan olahraga dengan mengadakan pertandingan-pertandingan tingkat kecamatan seperti pertandingan bola voli, pertandingan sepak bola, pagelaran-pagelaran kesenian yang menghimpun potensi kepemudaan disemua agama dan etnik.

- Kehadiran suatu lembaga LSM yang dikordinir oleh CARDI (Consortium for Assistance and Recovery toward Development in Indonesia) yang didanai oleh Komisi Eropa telah turut andil dalam memberi pengaruh positif bagi proses rekonsiliasi konflik yang pernah terjadi di tanah Poso dan memberi warna bagi pembangunan Poso dengan pendekatan kepemudaan, seluruh pemudayang ada di Kabupaten Poso dilibatkan dalam mencairkan ketegangan yang pernah terjadi. Ini terlihat dengan banyaknya Youth Center yang menjadi mitra kerja dari CARDI dan selama kurang lebih 4 tahun keberadaannya suasana kota Poso telah disulap menjadi kota yang damai dan aman untuk saat sekarang ini, terbukti dengan digelarnya suaUi kegiatan yang bertemakan "Bursa Kreasi Orang Muda" yang berlangsung dari 
tanggal 29 s/d 30 Maret 2008 yang di buka oleh bapak Bupati Poso dan dihadiri oleh unsur Muspida, tokoh agama dan tokoh masyarakat.

Departemen agama Kabupaten Poso dalam kebijakannya terhadap proses rekonsiliasi kedamaian masyarakat umat beragama akan lebih memberikan perhatian disektor kaum muda dengan melakukan penguatan dari penyuluh agama. Dengan metode ini diharapkan bisa melakukan pemberdayaan kepada masyarakat akar rumput, dan pengharapan itu melalui peranan generasi muda, apakah Islam, Kristen, Hindu, Budha dan Khatolik. Tokoh agama atau Penyuluh Agama yang diturunkan untuk tahun 2007 ini adalah mereka yang mengetahui dan memahami agama secara universal, kalau Penyuluh Agama Islam dia harus mengetahui konsep Rahmatan Lil 'Alamin dan kalau Nasrani harus tahu ajaran Cinta Kasih dan Cinta Damai.

Departemen Agama juga mendorong penguatan lembaga-lembaga keagamaan. Misalnya untuk Agama Islam akan bekerjasama dengan lembagalembaga keagamaan seperti NU, Muhammadiyah, Al-Khaeraat dan organisasi Islam lainnya untuk berperan aktif dalam kegiatan Hari-hari Besar Islam seperti peringatan Maulid Nabi, Isra' Mi'raj, tahun Baru Islam, perayaan Idul Fitri dan Idul Adha dan sebagainya. Begitu juga untuk agama Kristen akan merangkul seluruh lembaga keagamaannya dalam melaksanakan kegiatan keagamaannya seperti, Hari Natal dan Tahun Baru, atau Perayaan Paskah dan lain-lainnya. Lembaga-lembaga agama dan keagamaan tersebut akan menjadikan momen hari-hari besar agama sebagai proses pencerahan bagi umat.

Khusus untuk pemuda pola-pola yang dilakukan oleh Kantor Departemen Agama Kabupaten Poso yang menyentuh langsung kepada generasi muda itu harus selalu berkoordinasi dengan program-program yang ada di Kanwil Agama Provinsi Sulawesi Tengah dan program yang ada di pusat semacam kemarin ada kemah pemuda lintas agama, dan dialog pemuda akan kita lakukan secara intens. (Bulletin Krespo : Wawancara Kakandepag Kabupaten Poso, Drs. H. Nasrudin L. Midu, M.Ag)

Selain kebijakan pembentukan mental spiritual keagamaan pemerintah juga melakukan pembangunan kembali terhadap sarana pribadatan seperti masjid dan kereja yang rusak akibat kerusahan serta pembangunan sarana sekolah/ madrasah agar proses pendidikan agama dan keagamaan kembali bergairah.

Kantor Departemen Agama Kabupaten Poso melakukan berbagai upaya pemberdayaan bidang pendidikan agama dan keagamaan, Pemerintah kini telah mencanangkan tiga sasaran pokok, yaitu: 
1. Peningkatan pemerataan pendidikan bagi masyarakat

2. Peningkatan kualitas pendidikan, dan

3. Optimalisasi sistem pengelolaan pendidikan.

Untuk maksud tersebut, maka Departemen Agama RI mempunyai kewajiban untuk merumuskan kegiatan-kegiatan dalam mewujudkan tiga sasaran pokok bidang pendidikan tersebut. Kantor Departemen Agama Kabupaten Poso sejak awal telah memberdayakan masyarakat melalui Optimalisasi Pendidikan Nasional, khususnya pend idikan keagamaan.

Dinamika pendidikan keagamaan tersebut, selain menjadi landasan pemerintah dalam menyusun strategi pengembangan pendidikan agama dan keagamaan, juga menjadi ciri khas dari program pendidikan agama dan keagamaan pada Departemen Agama.

Oleh karenanya, Kantor Departemen Agama Kabupaten Poso secara terus menerus akan melakukan langkah-langkah pemerataan dan perluasan pendidikan bagi seluruh warga masyarakat dan melakukan upaya-upaya peningkatan kualitas pendidikan tersebut. Namun demikian, kelembagaan madrasah yang melayani pendidikan masyarakat pada umumnya masih dilaksanakan secara swakelola dengan segala keterbatasan dan kelemahan-kelemahan yang cukup serius, kelemahan-kelemahan itu bisa terselesaikan atau berkurang apabila Sistim Pendidikan Nasional bisa diterapkan sehingga antara pemerintah, madrasah dan masyarakat bisa memiliki visi dan misi yang sama.

Di sisi lain, madrasah juga diharapkan fungsi dan peranannya dalam upaya penyiapan SDM Indonesia yang berkualitas, serta berdaya juang (Kompetitif), bahkan lebih dari itu, out put pendidikan yang bermutu akan berpengaruh secara luas pula pada terciptanya Good Governance dan Civil Society. Dalam pengertian yang luas, madrasah mengandung arti tempat dan wahana yang diperuntukkan sebagai proses pembelajaran secara terarah, terpimpin dan terkendali.

\section{Implementasi Pendidikan Agama dan Keagamaan Pasca Konflik}

a. Aspek Input

\section{Sarana dan Prasarana Fisik}

Sarana pendidikan merupakan aspek terpenting dalam kelangsungan proses belajar mengajar pada lembaga pendidikan, dukungan sarana dan prasarana yang lengkap akan berdampak pada pencapaian tujuan pendidikan pada suatu 
lembaga pendidikan, dukungan sarana dan prasarana yang lengkap akan berpengaruh pada pencapaian tujuan pendidikan dalam suatu lembaga pendidikan.

Sarana dan prasarana fisik yang dimiliki oleh sekolah SMA Kristen GKST Poso sebelum terjadinya konflik seperti, Laboratorium/ ruangan praktek IPA, Rumah Dinas dan ruangan perpustakaan, computer, ruangan dapur bersama alat-alat lainnya sebagaimana yang dimiliki oleh sekolah lain sederajat dengannya di Kota Poso. Tapi sebagian besar sarana tersebut habis terbakar dan dijarah ketika terjadi konflik.

Kondisi sarana dan prasarana yang ada sekarang relatif masih sangat kurang akibat kebakaran dan penjarahan pada saat konflik dan yang tersisa hanyalah berupa : Ruang kelas 3 buah, ruang guru 1 buah, ruang kepala sekolah dan tata usaha 1 buah, kursi dan meja siswa 100 buah, kursi/meja guru 20 buah, kursi/ meja Tata Usaha 2 buah, feeling cabinet 2 buah, lemari buku 4 buah, kursi plastik untuk tamu 1 set, tape recorder 2 buah, computer 5 buah, printer 2 buah, microfon 1 buah, jam dinding 2 buah, mesin ketik manual 2 buah, kompor minyak tanah 1 buah. Sedangkan sarana gedung laboraturim IPA dan ruangan Perputakaan sudah di renovasi kembali tapi belum bisa dipergunakan karena sarana penunjangnya belum ada seperti alat-alat praktek untuk laboraturium dan buku-buku bacaan untuk perpustakaan.

Sarana dan prasarana yang dimiliki oleh SMA Negeri 3 Poso juga mengalami penj arahan ada beberapa inventaris milik yang dijarah seperti seperti kipas angin mushallah, peralatan drum band, alat-alat laboratorium bahasa, seng gedung sekolah, buku-buku perpustakaan, bahkan brankas diobrak-abrik tapi tidak sempat dibuka.

Kondisi prasarana yang dimiliki saat ini sudah cukup memadai dengan ketersediaan ruangan belajar sebanyak 19 ruangan, ruang kepala sekolah, ruang tata usaha, ruang guru, ruang serba guna, ruang perpustakaan, ruang keterampilan laboratorium IPA, laboratorium Bahasa, laboratorium computer, dan dilengkapi pula dengan ruang Osis, gedung olah raga, raung BP, mushallah masing-masing 1 buah.

Untuk sarana mobeler antara lain : meja/kursi siswa 770 buah, meja guru 72 buah, kursi guru 56 buah, kursi roda 2 buah, kursi lipat 27 buah, kursi plastic 110 buah, kursi lab. Bahasa 40, tape lab. Bahasa 40, lemari 27 buah, rak buku 10 buah dan lemari obat 2 buah. Sedangkan sarana dan prasarana penunjang kantor dan KBM antara lain : mesin ketik 2 buah (1 rusak ringan), mesin stensil 
Amiruddin

2 buah (1 rusak berat), computer 19 ( 2 rusak berat), printer 4 buah ( 2 rusak berat), amplifayer 2 buah. Peralatan kesenian (gitar 2 buah, suling 15 buah, tamtam 2 buah). Peralatan olah raga (bola kaki 3buah, bola volli 4 buah, bola takraw 2 buah, bola basket 2 buah, raket bulu tangkis 2 buah, net bola volli 3 buah, net tenis meja 1 buah, dan matras 1 buah).

Sarana dan prasarana yang dimiliki oleh MTsN Poso Kota telah memadai seperti, gedung pendidikan 4 buah, gedung perpustakaan 1 buah, gedung kantor 1 buah, gedung keterampilan 1 buah, laboratorium IPA 2 buah, computer 9 buah, printer 6 buah, mesin stensil 1 buah, mesin keitk 2 buah, telepon 1 buah, lemari kayu 27 buah, lemari kaca, rak kayu 7 buah, meja guru 49 buah, kursi guru 42 buah, kursi siswa 419 buah, meja siswa 342 buah, kursi tamu 1 set dan terdapat pula lapangan olah raga serta mushallah masing-masing 1 buah. Dan untuk kelancaran kegiatan maka kepala sekolahdiberikan sarana transportasi berupa 1 buah sepeda motor.

\section{Ketersediaan SDM}

Betapapun bagusnya suatu konsep, dalam pelaksanaannya semua itu akan tumpul jika guru agama sebagai ujung tombak di lapangan tidak memiliki kualitas spiritual, emosional, maupun intelektual yang memadai. Mengingat peran kependidikannya yang luar biasa strategis, mestinya penyiapan dan penghargaan terhadap guru-guru agama dilakukan dengan daya dan dana yang istimewa, tidak "ala kadarnya" seperti yang terjadi selama ini. Begitupun, tanpa dibarengi pembiasaan atau pembudayaan nilai-nilai luhur agamawi, kejujuran, kerendahan hati, ketulusan, kasih sayang, tanggung-jawab, dan sebagainya. Dalam perilaku individual seluruh civitas akademika maupun institusional sekolah, maka guru agama sekalipun akan terseok-seok memikul beban berat itu sendirian.

Secara umum mayoritas tenaga pengajar SMA Kristen GKST adalah lulusan Perguruan Tinggi (SI) demikian pulahalnyadengan disiplin ilmuyang dimiliki sesuai dengan mata pelajaran yang diajarkan (sesuai konpetensinya) seperti pada data yang ditemukan dilapangan. Jumlah guru yang ada di SMA Kristen GKST Poso sebanyak 18 orang dengan klasifikasi Strata Satu (S1) 15 orang dan Sarjana Muda (D3) sebanyak 3 orang. Ini menunjukkan bahwa tingkat profesionalisme tenaga pengajar di SMA Kristen GKST ini cukup tinggi.

Begitupun di SMA Negeri 3 Poso menunjukkan SDM yang dimiliki oleh tenaga pengajar cukup memadai karena dari 36 guru yang ada terdapat 33 guru dengan jenjang pendidikan SI (sarjana), dan selebihnya adalah D3 (diploma tiga). Sedangkan untuk pegawai tata usaha yang sebanyak 8 orang hanya satu orang yang lulusan $\mathrm{S} 1$. 
MTsN Poso Kota juga menunjukkan SDM yang dimiliki oleh tenaga pengajar cukup memadai karena dari 32 guru yang ada terdapat 30 guru dengan jenjang pendidikan SI (sarjana), dan jenjang D3 (diploma tiga) sebanyak 3 orang. Sedangkan untuk pegawai tata usaha yang sebanyak 6 orang hanya satu orang yang lulusan SI.

\section{Jumlah Siswa}

Rata-rata perbandingan jumlah siswa sebelum konflik dengan pasca konflik yang di himpun dalam penelitian ini menunjukkan penurunan jumlah siswa yang cukup signifikan di 3 sekolah yang menjadi sasaran penelitian, seperti yang terlihat di SMA Kristen GKST Poso, dulu siswa sekolah ini mempunyai siswa rata-rata pertahun kurang lebih 700 siswa, tapi untuk tahun ajaran 2008 hanya sekitar 41 orang siswa, yang terdiri kelas 1 sebanyak 8 orang siswa, kelas 2 sebanyak 22 siswa dan kelas 3 sebanyak 11 siswa.

SMANegeri 3 Poso untuk empat (4) tahun terakhir dari tahun 2005 s/d 2007 sudah mulai menampakkan perkembangan yang menggembirakan karena sektor pendidikan sudah mulai bergairah kembali utamanya keadaan siswa yang ada di SMA Negeri 3 Poso ini. Data yang kami olah menunjukkan jumlah siswa untuk tahun ajaran 2005/2006, yaitu sebanyak 586 orang siswa, tahun ajaran 2006/2007 sebanyak 611 orang siswa, dan tahun 2007/2008 sebanyak 559 orang siswa.

Untuk MTs Negeri Poso Kota jumlah Siswa pada 4 tahun terakhir yaitu dari tahun 2005 s/d 2008 adalah sebagai berikut: untuk tahun 2005 jumlah siswanya berjumlah 257 orang siswa, tahun 2006 sedikit mengalami penambahan dengan jumlah siswa 276 orang siswa, dan pada tahun 2007juga mengalami peningkatan kuantitas siswanya yang berjumlah 319 orang siswa, sedangkan untuk tahun 2008 terus mengalami peningkatan dengan jumlah siswanya berjumlah 326 siswa.

Ketersediaan Kurikulum dan Buku-Buku Pegangan

Kurikulum merupakan salah satu aspek yang sangat penting dalam pendidikan, walaupun unsur guru sebagai pendidik dengan berbagai tugas profesionalnya sering dipandang jauh lebih penting.

Kurikulum yang di pakai pada sekolah SMA Kristen GKST Poso dan SMA Negeri 3 Poso dalam melaksanakan proses belajar mengajar, mengacu pada kurikulum yang diberlakukan Dinas Pendidikan dan Pengajaran yaitu kurikulum 2004 (KBK) yang diterapkan mulai tahun 2004 dan kurikulum 2006 (KTSP) yang mulai berjalan dan disosialisasikan di sekolah ini. Sedangkan untuk MTs Negeri Poso Kota selain mempergunakan kurikulum 2004 (KBK) dan kurikulum 


\section{Amiruddin}

2006 (KTSP), juga memakai kurikulum Depag, artinya mata pelajaran umum $50 \%$ dan mata pelajaran agama $50 \%$.

\section{b. Aspek Proses}

\section{Proses Pengambilan keputusan dan Pengelolaan Institusi Sekolah}

Pengelolaan institusi Sekolah harus dilakukan dalam proses peningkatan keberhasilan pendidikan yang mengarah pada bagaimana peran para pengambil kebijakan dalam menentukan keberhasilan pendidikan tersebut. Secara umum ada 2 (dua) strategi kebijakan yang biasa diterapakan oleh lembaga-lembaga pendidikan dalam melakukan pengambilan keputusan yaitu proses terpusat pada pimpinan dan proses partisifatif yang melibatkan pihak-pihak yang terkait.

Seperti yang terlihat pada semua sekolah yang menjadi sasaran penelitian ini menunjukkan proses pengambilan keputusan yang dituangkan dalam sebuah kebijakan senantiasa menganut metode "buttom up" artinya segala masukan, ide atau gagasan semuanya terinspirasi dari kalangan guru, pegawai administrasi, masyarakat (komite sekolah), dan stakeholder lainnya. Gagasan tersebut disesuaikan dengan aturan dan mekanisme yang ada.

Pada proses pengelolaan institusi sekolah yang berbentuk yayasan (swasta) seperti SMA Kristen GKST Poso, pihak sekolah (kepala sekolah) tidak dilibatkan secara langsung artinya proses pengelolaan lembaga ditangani langsung oleh pengelola yayasan. Sedangkan di MTsN Poso Kota dan SMA Negeri 3 Poso yang berstatus Madrasah dan sekolah Negeri pengelolaan kelembagaan menggunakan pengelolaan partisipatif yakni seluruh komponen sekolah/madrasah dilibatkan seperti guru, komite sekolah untuk turut berkontribusi dalam memberikan masukan kepada sekolah/madrasah untuk meningkatkan kualitas lembaga dan memberikan solusi terbaik dalam peningkatan sarana dan prasarana.

\section{Proses Belajar Mengajar}

Pelaksanaan proses belajar mengajar yang dilakukan di semua lembaga pendidikan yang menjadi sasaran penelitian dominan bersifat kooperatif artinya kegiatan belajar maupun mengajar tidak terpusat kepada guru maupun siswa semata tetapi ada sinergi antara guru dan siswa sehingga terjadi transfer ilmu. Komite sekolah juga ikut terlibat khusus mengenai program tambahan seperti kegiatan keagamaan, pelatihan dakwah dan lain-lain.

Dalam pelaksanaan pembelajaran biasanya guru sudah jauh-jauh mempersiapkan materi-materi yang akan di berikan kepada siswa. Sehingga ada kesan bahwa tenaga edukatif mengajar secara profesional dan untuk 
pengembangan wawasan biasanya seorang guru mencari literatur-literaturyang berkaitan dengan profesinya untuk memperkaya referensi keilmuannya.

Di samping itu, siswa juga selalu diberikan tugas tambahan untuk dikerjakan di rumah dan ditargetkan waktu penyelesaian tugas tambahan itu, siswa yang tidak dapat mengerjakan tugas tersebut akan diberikan sanksi baik berupa pengurangan nilai maupun dalam bentuk hukuman lain.

Untuk meningkatkan kualitas lulusan khususnya di MTsN Poso Kota maka pihak orang tua murid, Komite Sekolah dan pihak sekolah duduk bersama dalam membicarakan tentang hal-hal yang perlu dilakukan dalam menghadapi Ujian AkhirNasional (UAN). Sehingga melalui hasil rapat pihak sekolah melaksanakan program Try Out Madrasah dengan memberikan les tambahan non stop selama tiga bulan dengan konsekwensi orang tua murid di bebani biaya les untuk anaknya sebesar Rp. 50.000,- setiap bulan. Tenaga-tenaga pembimbing didatangkan dari luar dengan latar belakang pendidikan Master (S2) sehingga lulusan yang ada di MTsN Poso Kota untuk tiga tahun terakhir nilai kelulusannya $100 \%$.

Lain halnya yang dilakukan oleh SMA Negeri 3 Poso pihak sekolah memberikan keleluasan kepada siswanya untuk mengikuti kursus-kursus di luar di samping mengikuti les-les sore yang dilaksanakan oleh guru-guru bidang studi dengan membebani siswa pembayaran tiap bulannya. Hal ini dilakukan untuk membekali siswa-siswa dalam menghadapi Ujian Akhir Nasional dan untuk meningkatkan mutu lulusannya.

\section{Proses Evaluasi Sekolah}

Sistem evaluasi yang dilakukan di tiga sekolah yang menjadi obyek penelitian hampir sama dengan yang dilakukan oleh sekolah lain. Proses evaluasi harian dilaksanakan oleh guru yang bersangkutan, evaluasi semester dilaksanakan oleh sekolah yang membentuk panitia dengan melibatkan guru-guru di lingkungan sekolah, sedangkan evaluasi Nasional (UAN) dilakukan secara terpusat yang membentuk panitia intern, kemudian panitia Sub Rayon yang melibatkan sekolah-sekolah yang ada di wilayah induk rayon tersebut. Setelah Ujian Akhir Nasional selain UAN dalam hal ini sekolah juga melaksanakan UAS (Ujian Akhir Sekolah) yang juga di bentuk panitia tim penyusun soal yang dilaksanakan di rayon sekolah dengan melibatkan semua anggota sub rayon turut melibatkan guru-gurunya untuk menyusun soal. Sehingga siswa-siswa tidak merasa kesulitan dalam mengerjakan soal-soal tersebut.

Untuk tahun 2008 ada tiga mata pelajaran yang dikelola oleh Dinas Pendidikan dan Pengajaran (P \& P), yaitu mata pelajaran IPA, IPS dan PPKn, sekarang khusus mata pelajaran IPA sudah dimasukkan dalan Ujian Akhir 
Amiruddin

Sekolah (UAS), dan mata pelajaran IPS dan PPKn di serahkan kepada sub rayon untuk menyusun soalnya.

\section{Proses Akuntabilitas}

Proses pertanggung jawaban lembaga pendidikan baik kepada pemerintah maupun kepada masyarakat berjalan dengan lancar. Pihak sekolah/madrasah senantiasa koordinasi kepada pihak pemerintah dan melakukan bekerja sama yang baik dengan mengikuti semua sistem atau aturan yang telah ada.

Demikian pula pertanggung jawaban terhadap masyarakat (orang tua murid) senantiasa memberikan pembinaan dan bimbingan kepada mereka sebaik mungkin, khususnya dalam hal peaksanaan ujian, telah dilakukan berbagai upaya dalam rangka pencapaian mutu luaran sehingga mampu bersaing dengan sekolah unggulan lainnya dan dapat diterima diberbagai perguruan tinggi baik negeri maupun swasta.

\section{Aspek Output}

Standar kualitas out put yang ingin dicapai dengan baik, dapat dilihat dari nilai para lulusan yang telah memperoleh nilai atau angka yang melewati standar nilai yang ditentukan oleh pihak pemerintah. Demikian pula dengan perbandingan NEM yang lulus dengan NEM yang ideal tercapai secara efektif dan produktifitas perbandingan NEM tahun yang lalu dan sekarang tercapai karena adanya peningkatan dari tahun ketahun.

Dari hasil penelitian yang telah dilakukan di 3 sekolah telah menunjukkan bahwa nilai Ujian Nasional untuk SMA Negeri 3 Poso pada tahun 2007 pada program studi IPA nilai kelulusannya $100 \%$, untuk Program Studi IPS nilai kelulusannya 96,06 sedangkan untuk Program Studi Bahasa nilai kelulusannya hanya mencapai 50\%, dan untuk MTs Negeri Poso Kota, out put yang dihasilkan cukup signifikan karena ditinjau dari jumlah siswa yang lulus rata-rata diatas 90\%. Sedangkan untuk SMA Kristen GKST Poso tingkat kelulusan siswanya sangat dibawa harapan yaitu hanya $17,14 \%$ dari 35 orang siswa yang ikut Ujian Nasional untuk program studi IPS, dan tingkat kelulusan untuk program studi IPA hanya $22,22 \%$ dari 9 orang siswa atau hanya 2 orang siswa yang lulus.

\section{PENUTUP}

\section{A. Kesimpulan}

Kerusuhan yang terjadi di Poso telah berlangsung sejak 1998, secara sosiologis memiliki akar permasalahan yang multi dimensional, diantaranya dilatar 
belakangi oleh aspek politik, ekonomi, kecemburuan sosial, supremasi hukum, Suku dan Agama serta Ras (SARA). Namun dari akumulasi permasalahan, nampaknya masalah "politik" dan "Kecemburuan Sosial" sebagai akar utama masalah, di samping masalah suku, ras dan agama (SARA).

Pembinaan dan pengembangan pendidikan agama dan keagamaan disekolah atau madrasah perlu diupayakan secara maksimal (optimalisasi) demi untuk menghasilkan madrasah yang bermutu yang mampu berperan sebagai wadah edukasi, sosialisasi, dan trasformasi. Agar pembinaan pendidikan agama dan keagamaan di madarasah/sekolah dapat dilakukan secara efektif dan efesien.

Agar implementasi pendidikan agama dan keagamaan benar-benar mampu menjalankan fungsi dan tujuannya dalam mencerdaskan kehidupan bangsa serta mengembangkan manusia Indonesia seutuhnya, perlu dikembangkan dan dilaksanakan program pendidikan pada semuajenisdanjenjangyang dapat berfungsi sebagai lembaga sosialisasi, dan pembudayaan berbagai kemampuan, nilai, sikap, dan akhlak yang dituntut oleh masyarakat Indonesia yang maju adil dan makmur, serta demokratis berdasarkan pancasila dan Undang-Undang Dasar 1945.

\section{B. Rekomendasi}

Upaya penyelesaian kerusuhan Poso hendaknya dilakukan secara konprehensif dan simultan. Rekonsiliasi kultural hendaknya dilakukan secara kontinyu oleh pihak pemerintah baik pusat maupun pemerintah daerah.

Pendidikan agama dan keagamaan di daerah yang pernah berkonflik, perlu ditingkatkan terutama dalam hal mengatasi operasionalisasi lembaga pendidikan yang dirasakan semakin mahal, baik operasionalisasi infrasturktur maupun mental spiritual keagamaan.

Dalam hal kebijakan pemerintah pasca konflik perlu mengintensifkan dialog baik antar umat beragama maupun intern umat dan memperkuat Forum Komunikasi Antar Umat Beragama (FKUB) dalam merehabilitasi ingatan sosial (social memory) masyarakat yang diakibatkan oleh konflik sosial, kearah kebersamaan.

\section{DAFTAR PUSTAKA}

Abdul Wahab, S. 1997. Analisis Kebijaksanaan dariFormulasike Implementasi.Kebijaksanaan Negara, Jakarta: BumiAksara.

Aditjondro, George Junus, Dr (t.t). Dibalik Heboh dan Pro Kontra Eksekusi Tibo dkk, Naskah yang belum diterbitkan. 
Amiruddin

Al-Anshari, Fauzan dan Ahmad Suhardi (Ed), Tragedi Poso, Jakarta: Departemen Data dan Informasi Majlis Mujahidin Indonesia, bekerjasama dengan Forum Silaturrahim dan Perjuangan Umat Islam Poso, 2006.

Azizy Qadri, MA dalam Drs. H. Abdul Hamid, M.Ed dan Drs. H. A. Kadir Jaelani, M.Pd (Ed) Profesinalisme Pengawas Pendais, Departemen Agama RI Direktorat Jenderal Kelembagaan Agama Islam, Jakarta. 2003

Badrun, Patombongi, Solusi Konflik Sosial dengan Pendekatan Sosial Budaya. Balai Penelitian Lektur Agama Makassar. 2002.

Basri, Hasan Cik. Pilar-pilar Penelitian Hukum Islam dan Pranata Sosial, Cetakan. Pertama, PT. Raja Grakindo Persada, Jakarta. 2004.

BPS Kabupaten Poso Kabupaten Poso dalam Angka Tahun 2006.

—, Kecamatan Poso Kota dalam Angka Tahun 2006.

Budiman, dalam A.W. Widjaja. Drs, Manusia Indonesia, Individu Keluarga dan Masyarakat, Akademika Pres Sindo, Jakarta. 1986.

Bulletin Krespo, Merah Putihku di Langit Kelabu Tanah Poso, Edisi IV, Juli-Agustus. 2007.

Bulletin Krespo, Peran Utama Generasi Muda dalam Proses Rekonsiliasi di Kabupaten Poso akan lebih mendapat Perhatian, Edisi 1. Januari. 2007.

Depag Agama Kabupaten Poso, Data Kebutuhan Guru Madrasah dan Guru Pendidikan Agama di Sekolah tahun 2007.

E.Toeke, Idrus Hi. Drs, Menyatukan Pandangan dalam Semangat Imani Membangun Maluku Bersaudara, Majelis Ulama Indonesia Provinsi Maluku, Ambon. 2006.

EDUKASI, dalam "Standarisasi Pendidikan Agama dan Keagamaan" Puslitbang Pendidikan Agama dan Keagamaan. Badan Litbang dan Diklat Depag RI. Jakarta. 2007.

Hasarin dalam Muhammad Daud Ali, Hukum Islam, Pengantar Ilmu Hukum dan Tata Hukum Islam di Indonesia, Cet. Kesebelas, PT. Raja Grakindo Persada, Jakarta. 2004.

Islamy, M Irfan. 2001. Seri Policy Analysis. Malang: Program Pasca Sarjana Universitas Brawi jaya Malang.

K.J. Veeger. "Realitas Sosial" Refleksi Filsafat Sosial atas Hubungan Individu Masyarakat dalam Cakrawala Sejarah Sosiologi. PT.GramediaJakarta. 1986.

Liliwari, Alo. Dr. Prof. Prasangka dan Konflik, Komunikasi Lintas Budaya Masyarakat Multikultur, FKIS Yokyakarta, Yokyakarta. 2005.

M. Poloma. Margaret. Sosiologi Kontemporer, diterbitkan bekerjasama dengan Yayasan Solidaritas Gajah Mada (YASOGAMA). Cetakan Pertama. PT. Rajawali. Jakarta. 1984

Mazhari, Husain (Penerjemah), Pintar Mendidik Anak, Panduan Lengkap bagi Orang Tua, Guru dan Masyarakat berdasarkan Ajaran Agama Islam, Cet. Keenam. PT. Lentera Basritama, Jakarta. 2003.

Muryanis. Hj. Dra. M.Ag dan Drs. H. Romli M.Hum. Pendidikan Luar Sekolah, Departemen Agama RI Direktorat Jenderal kelembagaan Agama Islam, Jakarta. 2003.

Nurul Huda (editor), Pedoman Majelis Taklim, (Jakarta: Kordinasi Dakwah Islam (KOD1) DKI Jakarta, 1990).

S.Thahir. Lukman. dalam "Harmoni", Konflik dan keretakan Sosial: Belajar dari Pengalaman Konflik actual di Poso, Sulawesi Tengah. Puslitbang Kehidupan Keagamaan. Balai Litbang dan Diklat Departemen Agama RI. Jakarta. 2007. 